\title{
Berlin Tempelhof: From Heritage Site to Creative Industry Hub?
}

\section{Dagmar Zadrazilova}

Independent Researcher

\begin{abstract}
Tempelhof Airport in Berlin mirrors the political, social and cultural developments in the capital and - broadly - in the whole country. Tempelhof has witnessed the heyday of the 1920s aviation, figured in the National Socialists' power politics and acquired a reputable status in the course of the 1948/49 Berlin Airlift. During and after the Cold War, Tempelhof had been functioning as an airport, before it was closed down amidst protests in 2008. Today, the vast grassy airfield is open as a park, whilst various plans are being devised for the future usage of the former airport building.
\end{abstract}

October 2018 marked the 10th anniversary since the air traffic had been discontinued. It is, therefore, an appropriate occasion to look at the Tempelhof case anew. This paper attempts to shed light on how the manifold history and symbolic value of Tempelhof Airport is - or is not - being reflected within the current usage of the site, as well as in various proposals for its future developments, and how the latter correspond to the unique atmosphere of this place. Tempelhof's rich and unusual history re-emerges in virtually every decision about the future of the site: from the idea to turn the site into an encompassing 'creative hub,' to economic questions (making the building more accessible to the public, using the terminal hall and the apron for mass events, and the like), right to the opposition of large groups of locals to the Senate of Berlin's politics.

Keywords: Tempelhof, Airport, Berlin, Heritage, Creative Hub

\section{The Past}

The very site where the grassy airfield is located today has been unbuilt for centuries. It was used as a parade ground and, in the nineteenth and early twentieth centuries, as a suitable space for amateurish aerial experiments (Ahlbrecht \& Henning 2008). Regular air traffic began in 1923. In 1926, Deutsche Lufthansa was founded and Tempelhof became its home airport. When a new modern and cleanly rendered terminal building was unveiled several years later, Tempelhof was already one of the busiest airports in Europe, next to Paris and London (Meiners 2011; Ayrault \& Bowdler 2000). After the National Socialists had come to power in 1933, Tempelhof became part of the plans to transform Berlin into 
Welthauptstadt Germania. Ernst Sagebiel, an NSDAP member but otherwise a man uninterested in politics, was assigned the task of designing a new building, one that would represent the ruling political discourse in a grand style (Dittrich 2005, 2006).

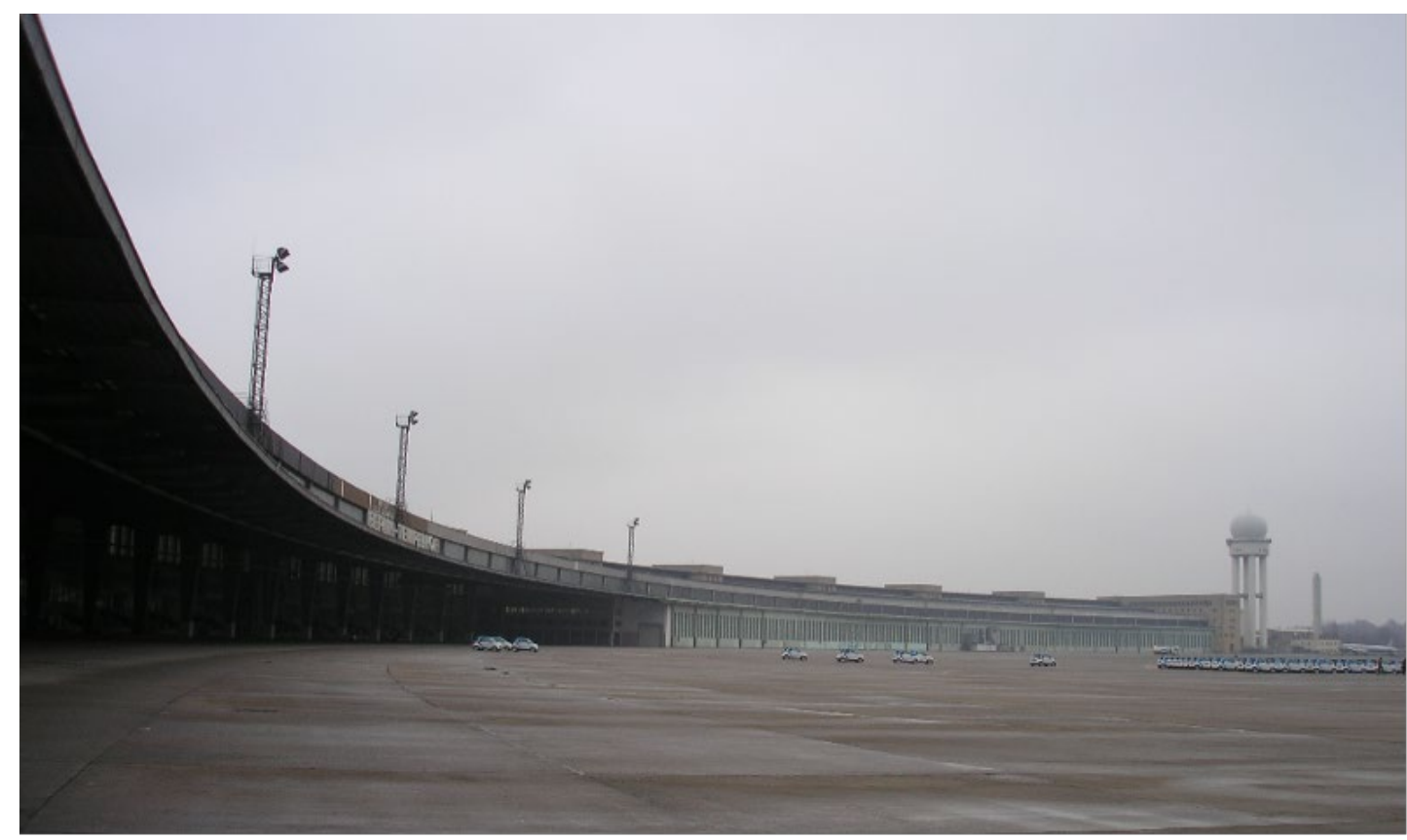

Figure 1. Tempelhof airport: a view from the runway (Photograph taken by author).

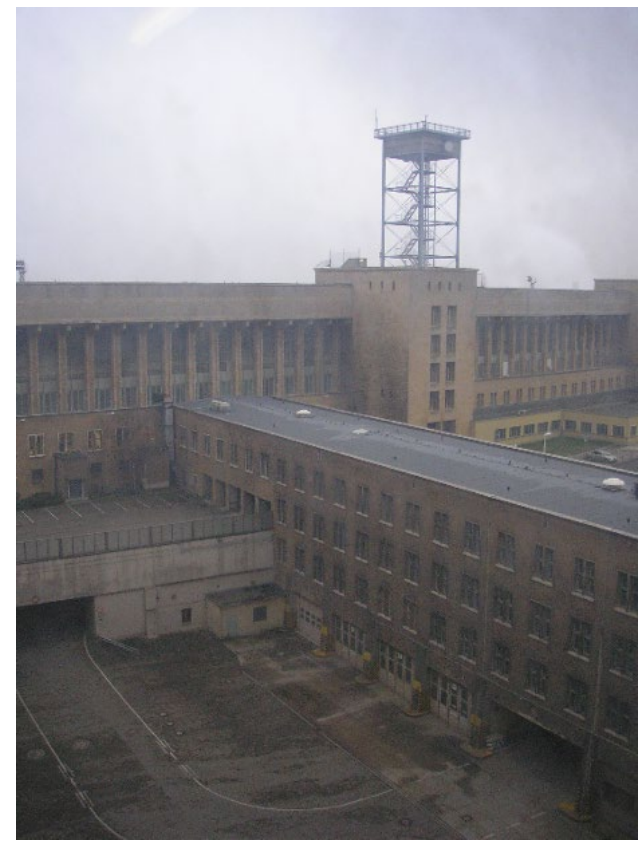

Figure 2. Tempelhof airport: one of the inner courtyards (Photograph taken by author).
Even though the edifice (Fig. 1) has never been finished (technically speaking), back then it was one of the biggest monolithic standing structures in the world (Figs. 2 and 3), together with the Merchandise Mart in Chicago. Although the statistics changed after Pentagon was opened in 1943, the sheer monumentality of Tempelhof has been one of its defining characteristics since the end of the 1930s and plays a key role - explicitly or otherwise - in virtually all discussions about the current and future use of the site today. Tempelhof is the biggest listed building in Europe and its intriguing materiality cannot be disregarded.

Another defining characteristic within the story of Tempelhof - next to the site being an embodiment of airmindedness (Adey 2011, 2010; Cwerner et al. 2009; Gordon 2008) ${ }^{1}$ - is the decisive volte-face of Berlin's post-war history: the perception of Tempelhof changed completely when the site turned into the focal point of the 1948/49 Berlin Airlift, when

\footnotetext{
1 Adey 2011 and Adey 2010 expand on the concept of airmindedness, whilst Cwerner et al. 2009 deal with aeromobilities. For more on the phenomenon of an airport per se, see Gordon 2008.
} 
inhabitants of West Berlin, sealed off by the Soviets, were being supplied by air for many months (Huschke 2008; Reese 2009). As a consequence, Tempelhof started to be seen as a 'Gate to Freedom' and gradually acquired a celebrated and deeply symbolic status, especially - and not surprisingly - amongst West Berliners. This West-East estrangement has not quite disappeared from the current discourse on the future of the site, although to draw a strict line between the two categories would be, of course, too simplistic. Thus, Tempelhof could be seen as a lieu de mémoire (Nora 1989, 1996); an Erinnerungsort, or a realm of memory (François \& Schulze 2001); a palimpsest (Hyussen 2003); a place inseparable from its 'ghosts' (Ladd 1998) as well as being flooded with memory-work (Till 2005).

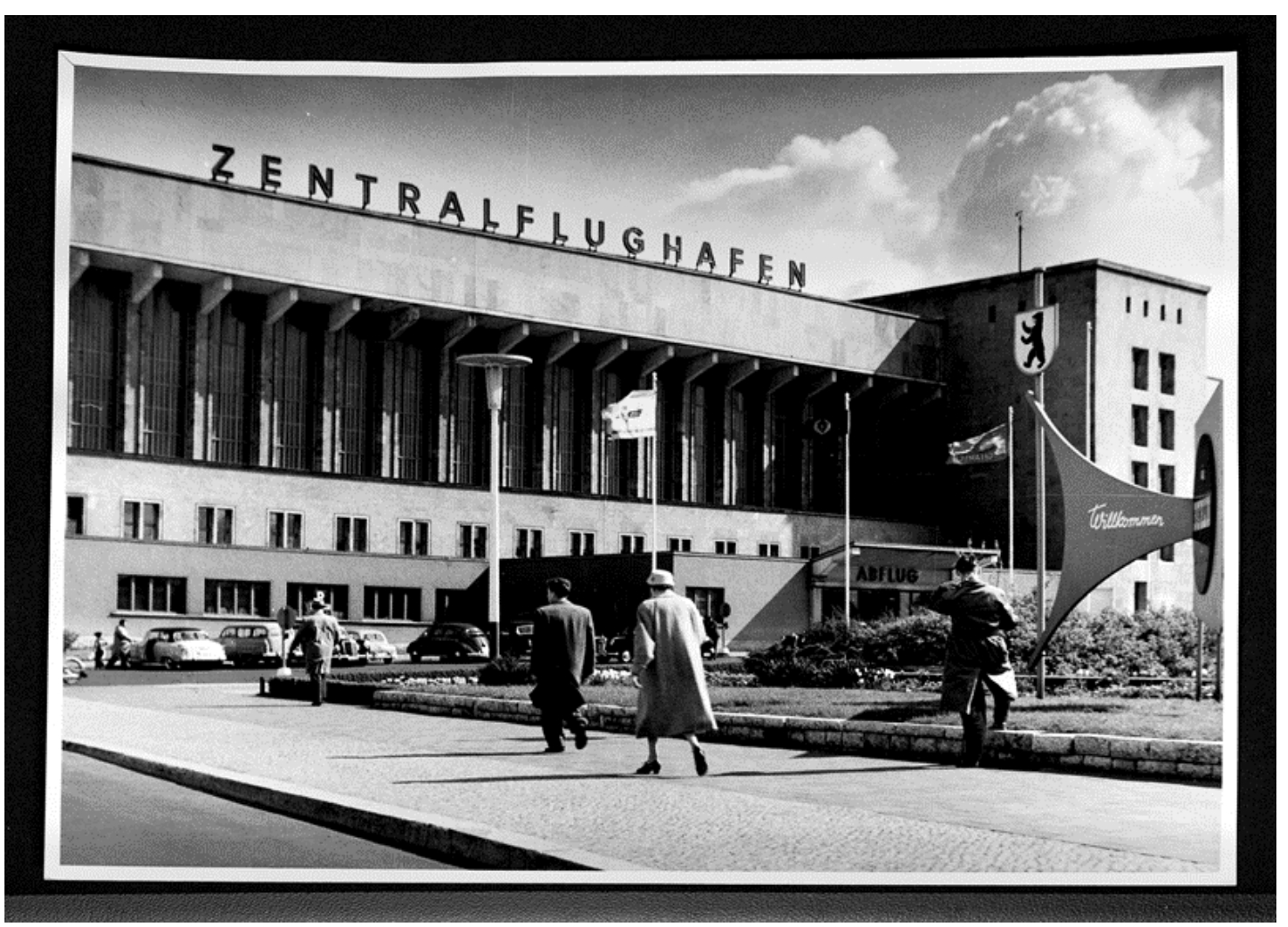

Figure 3. Tempelhof airport: post-war operation (DHM, BA 97/2356)

Tempelhof operated as an airport during the Cold War era and its closure in 2008 materialized only after fiery debates, protests, and amidst accusations amongst particular opposing camps (Schoelkopf 2008). Now, more than a decade after the air traffic had been discontinued, the voices of those who campaigned for the air traffic to be preserved have not been silenced, especially given the complicated status of the unfinished Berlin Brandenburg international airport ${ }^{2}$ (scheduled to be opened at the end of October 2020, years behind its originally planned inauguration), as well as speculations about the future of the Berlin Tegel airport ${ }^{3}$ (planned to be shut down, although a large part of Berliners strongly opposes this proposal, see Alberts et al. 2009).

\footnotetext{
${ }^{2}$ Officially 'Willy Brandt Airport, Berlin Brandenburg,' frequently referred to as 'BER'

${ }^{3}$ Officially 'Berlin Tegel "Otto Lilienthal" Airport.' Air traffic at Tegel is planned to be discontinued in May 2021. See Fabricius 2019.
} 


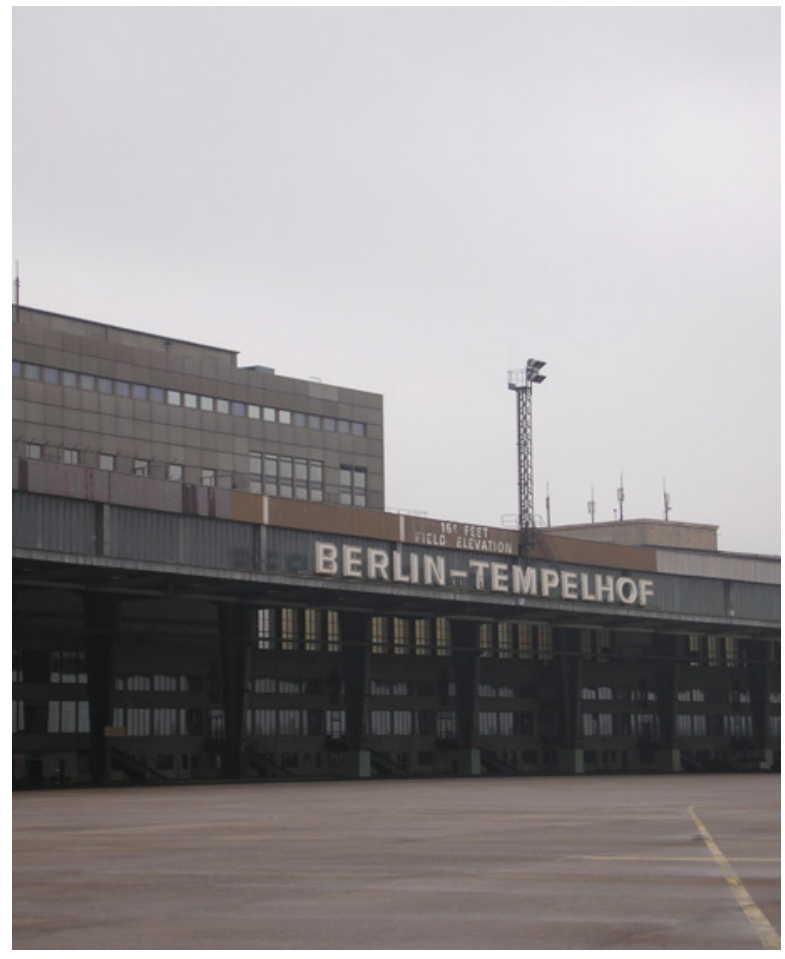

Figure 4. Tempelhof airport: a view from the runway towards the terminal, overseeing a part of the apron (Photograph taken by author).

The use of the terminal building and the adjacent apron (Fig. 4) for temporary housing during the migrant crisis of 2015 means that a piece of legislation, prohibiting any construction on the site, might now be revoked. This illustrates the vital role of Tempelhof within the metropolitan politics and planning, all the more so that the said piece of law was introduced after the 2014 referendum in which the majority of participants had decided to keep the airfield completely unbuilt and freely accessible for good.

\section{The Present}

Opening of the vast airfield to the public in May 2010 was criticised by those who perceived jogging, kiteflying, skateboarding or quirky gardening as disrespectful given the fact that near the field used to operate a concentration camp called Columbia Haus (1934 - 1936), and forced labourers were assembling bombers in the underground space of the building. Despite these criticisms, the field became notably popular with locals and tourists alike. For some time after 2010, the airfield-cumpark was branded as 'Tempelhof Freedom' (Tempelhofer Freiheit). Associating freedom with some of the above-mentioned darker periods was perceived as controversial by some. Currently, the site is presented simply as 'Tempelhof Airport' (Flughafen Tempelhof). ${ }^{4}$ What is at stake is avoiding Tempelhof turning into a non-place (Augé 2008) or becoming an example of kitsch geographies: a location devoid of meaning yet pretending to have safely kept - in an entirely artificial manner - the pleasant atmosphere of its one-time splendour (Atkinson 2007).

The voices arguing for a greater historical awareness of Tempelhof's past were finally heard, however: in 2013, the Senate of Berlin (the local government of the Land Berlin) supported archaeological excavations on the edge of the field near Columbiadamm, where the housing barracks for forced labourers once stood (Ausgrabungen-Tempelhof 2018). In addition, a number of historians and archaeologists from Germany and further afield constituted an advisory committee. This measure should ensure that the problematic aspects of Tempelhof's past will not be forgotten.

\footnotetext{
${ }^{4}$ This information was obtained during focus groups that I conducted with the guides at Tempelhof in 2012 and 2013, as well as during several tours that I participated in.
} 
However important and praiseworthy these scholarly initiatives are, they remain somewhat in the shadow of the plethora of free-time activities that the field offers and that most users relate to. This has several reasons.

Firstly, the site is located very close to the city centre. The field can be easily reached by public transport and even on foot. In an age of rapid urbanization and an increasing problem of disappearing greenery in urban areas, this can almost be considered a luxury. One only needs to look at a city map of Berlin to see how the unusual round shape of the field, embraced by the semi-circular airport building, stands out conspicuously from the surrounding sea of housing development.

Secondly, the grassy field influences the metropolitan climate markedly positively, especially during hot summers when it cools down the overall atmosphere in the city. The green area is also home to many species, and the 'sea of meadows' (Wiesenmeer) on the field helps to support Berlin's biodiversity.

Thirdly, it is the surreal settings of the premises. The immense green field of some 350 hectares serves as a sanctuary, the effect of which, however, differs from a typical city park or garden, the latter usually meticulously well-kept. It is the sheer space of an unbuilt piece of land, completely flat, virtually devoid of trees and stretching almost as far as the eye can see, that forms a crucial part of the attraction of the site. The field is one of the most extensive inner-city areas anywhere in the world and this fact, I argue, should seriously be taken into consideration: once re-developed (even if partially), such an exceptional and unparalleled space will be impossible to re-create.

Fourthly, the field essentially connects several neighbourhoods together, not only geographically, but also socially. Given the fact that the loyalty of citizens to their particular quarter (Kiez) has been traditionally strong in Berlin, the organic interconnectedness of Kreuzberg, Tempelhof and Neukölln through sharing the edges of the field could be understood as a natural topographical and community bonding agent. This has been increasingly important considering the rising tensions amongst various ethnic and religious minorities (Die Welt 2016a, 2016b; Baban 2006).

The popularity of the field was confirmed in 2014 when Berliners voted down the Senate of Berlin's proposal to redevelop the edges of the field. Possible redevelopment was, of course, only feasible on a field devoid of aerial activity: therefore, the questions of cancelled aerial traffic, redevelopment plans and the overall use of the field were related to each other. The whole process went hand in hand with a conspicuous anti-development campaign. Several groups of citizens gradually crystallized, each advocating the needs and interests of its stakeholders. Aviation enthusiasts, hobby pilots and some former employees from the airport were campaigning against the air traffic being discontinued. Their arguments included economic viability, tradition and benefits of a city airport for a leading metropolis that Berlin aspired to become. The opposing camp complained about unbearable noise levels and a lack of safety, due to the fact that the aircraft landing/taking off were passing close to blocks of flats near the field. Opponents to the city airport were 
also concerned that it could turn into an airport "for the rich." There were other groups, whose ideas often overlapped, or who were agitating for/against one solution or another because of various reasons. The environmentalists wished for cleaner air and more greenery. The allotment gardeners and community-minded locals welcomed transforming the field into a social place where different kinds of people could meet. The fault lines between these opinions were not clearly cut, yet they were strong enough to resurface in debates about the current and future use of the field and, in a relation to it, of the building. Furthermore, the ongoing debate, including the tumult it has caused, has been observed from abroad, too, and commented upon (The Economist 2012).

At that time, the edifice housed several institutions, including a central police station, the German Meteorological Office, a lost property office, and several other organizations and small businesses, some of which are still located there. In addition, interested visitors can now book a tour to see several historically relevant spaces within the colossal structure. The guides are trained in the history of the site and the edifice. Most of them are true devotees, some of them are former employees, capable of conveying captivating stories from times when Tempelhof was a gate to West Berlin for all sorts of internationally renowned personalities. ${ }^{5}$ Hiring former employees of the airport to guide tourists around was clearly an intelligent idea: not only feel these individuals valuable, but the story of the site is being transmitted essentially via oral history methods, in a completely natural way. Visitors include West Berliners (to see 'their' airport from behind the scenes), East Berliners (to see what was really the substance of the 'Tempelhof myth'), Germans from other areas of the country (to learn more about the significance of the site, closely connected to the significance of Berlin itself) and tourists from abroad (Bildungstouristen, 'hipsters,' curious persons or simply those who somehow found their way there, not knowing what to expect). These categories are simplistic and instructive, yet they do exemplify the breadth of appeal that Tempelhof emanates.

Nevertheless, a coherent concept for the use of the building, including the extensive apron, seems to be missing. To make the building more economically viable, it has been let out to companies organizing concerts of popular music, fashion shows, car racing and all kinds of similar activities. Whilst the former often made inhabitants from the neighbouring areas complain about unbearable noise levels (Strauss 2013) and general disruption caused by litter and some sorts of socially deplorable behaviour, fashion events provoked comments about greediness, tastelessness and a lack of decency, car racing could usually be justified thanks to its relative closeness to aviation and suitable terrain conditions that the field offers. Some members of the younger generations of Berliners or would-be Berliners might perhaps dismiss all these objections as petrified grievances of grumpy old individuals, yet this is not the case. The over-commercialisation of Tempelhof was aptly expressed by Anselm Kiefer, one of the most prominent post-war German artists. He summarised the situation thus: “...they have fashion shows at Tempelhof and all this nonsense. There's an office, an ice skating rink - it's trivialising. I wrote [ to the 
Berlin's cultural department] a letter, saying "In the cathedral, you don't bicycle." I spoke with Norman Foster and he said it was a pity they didn't do something dignified with the locality" (Needham 2011).

This is not to say that the building and the field should not be commercially utilised. The opposite is desirable: it is in the interest of culture, society, economy and even politics that the premises are wisely used, thus escaping the sad fate of - for example - the beach resort Prora on the island of Rügen. This is what leads us back to the decision to abandon the air traffic in favour of leisure use in the first place, and to the lengthy back-and-forth negotiations that followed. Did the Senate of Berlin (specifically its section for urban development, the Senatsverwaltung fur Stadtentwicklung) and the Tempelhof Projekt GmbH a body in charge of Tempelhof and, in itself, a 100\% subsidiary of the Land Berlin - have a clear idea what to do with some $307,000 \mathrm{~m}^{2}$ of office space, constituting 7, 250 rooms (Thf Berlin a), and 350 hectares of the unused airfield? Very probably not, and that was one of the reasons why the happenings at Tempelhof after 2008 have been less than smooth. Civil servants in charge of Tempelhof have apparently attempted to make the public a part of the decision-making process (Rechenberg 2013), which in itself is a highly commendable effort. Nonetheless, the flood of various 'ideas competitions' (Ideenwettbewerbe), 'city conferences' and 'public workshops' has not been used effectively enough and many of potentially valuable outcomes ended in vain, which is regrettable (Zadrazilova 2020).

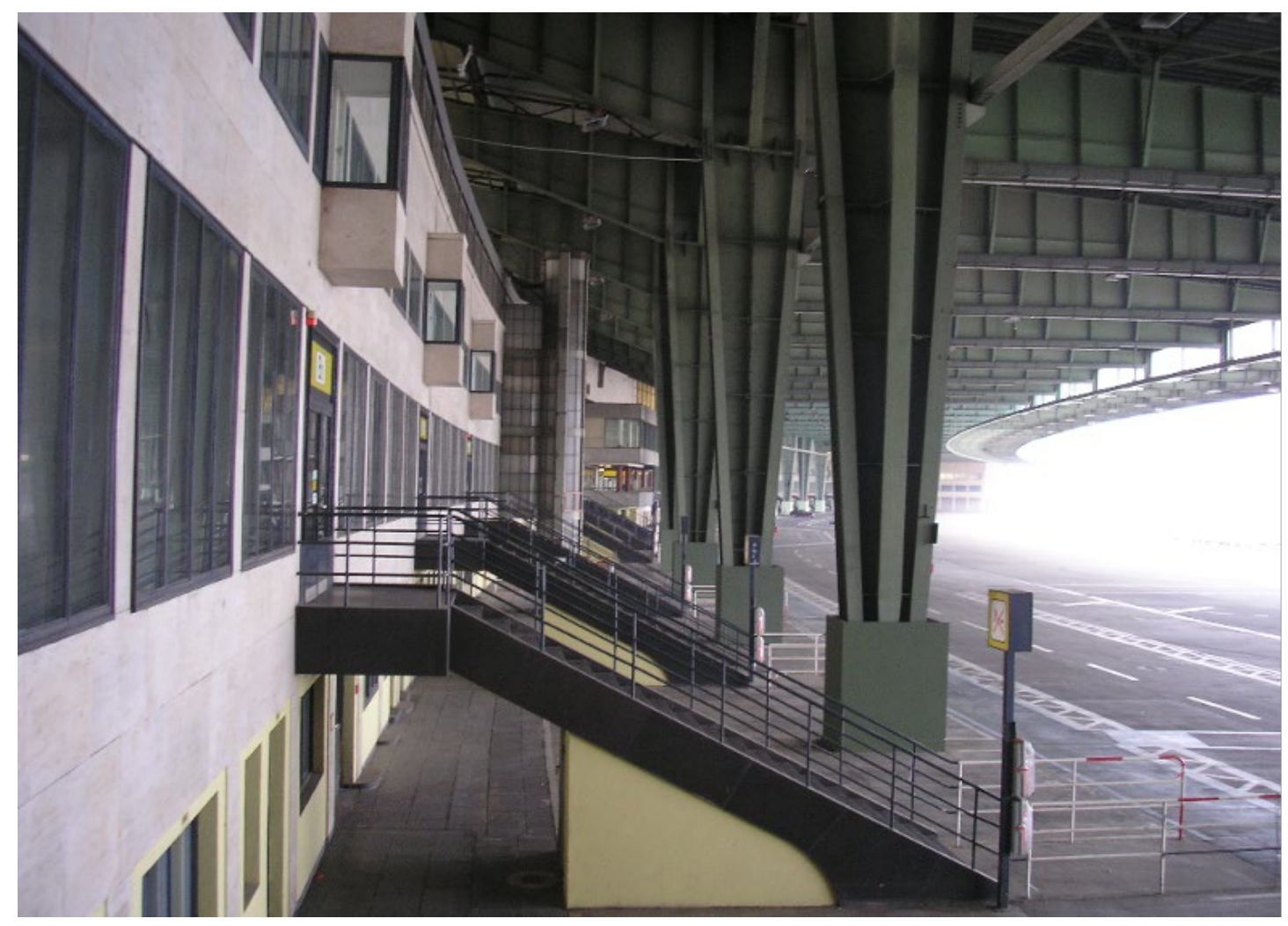

Figure 5. Tempelhof airport: the steel roof of the building boldly stretching along the outer side of the semicircular building (Photograph taken by author) 


\section{The Future}

What are the formal plans and accomplishments?

One. To refurbish parts of the building, according to the principles of heritage care (Denkmalpflege). Lack of funding has been, unfortunately, a persisting issue, especially given the lamentable state of the metropolitan budget.

Two. To move the Allied Museum from the rather remote Clay-Allee in Dahlem to the hangar No. 7 at Tempelhof. With regard to the importance of Tempelhof for the Airlift, as well as the missing exhibition space for original aircraft on the Dahlem premises, this seems to be a reasonable step. More nostalgic visitors might point out that it was the suburban areas of West Berlin - such as Dahlem - that have been somehow conveying the spirit of thoroughly westernized freedom, and perhaps even a certain style of daily living, across other areas of post-war Berlin. The hangars at Tempelhof could hardly offer such an intimate atmosphere that the former cinema-turned-museum radiated in Dahlem. This quiet and affluent suburb, filled with many buildings that were used by the Allies, creates something of a safe, welcoming microcosm. Nonetheless, moving the museum to Tempelhof certainly seems to be a decision that is more or less understood and welcomed by the public. The aim of the authorities is to establish another history-related site in the city, attracting locals, tourists from across Germany, and from afar.

Three. To make accessible the tower that is part of the building, thus enabling visitors to enjoy the panoramic view over the city. According to the official report, this is one of the measures to integrate the edifice more tightly into the urban fabric of the surrounding district (Thf Berlin b).

Four. To open a promenade with a gallery on the roof (Fig. 5) (Thf Berlin c). The work was scheduled to be finished in 2022 . The unique, $1.2 \mathrm{~km}$ long roof will turn into a 'history gallery', with specially designed panels enabling sightseers to 'travel in time.' The idea to use the roof, however, goes back to the late 1930s when an immense grandstand for dozens of thousands of spectators was part of the overall design. Regardless of politics, using the roof in a sensible way seems to be fitting, as long as principles of heritage care are maintained. The significance of this project is corroborated by the support of the Federal Ministry of the Interior, Building and Homeland (Bundesministerium des Innerm, für Bau und Heimat): the rebuilding proposal will be financed through the Ministry's programme called National City Planning Projects (Nationale Projekte des Städtebaus) (Thf Berlin d).

Five. To create a new visitor centre on the cour d'honneur in front of the imposing entrance hall (Thf Berlin e). This goal has been announced as achieved, scheduled to function from March 2020 onwards (Thf Berlin f). How adding a new structure relates to the grade-listed status of Tempelhof is hard to ascertain. The official information is rather vague, proper visual studies of the new addition are missing. The centre, called CHECK-IN, is described as a multi-purpose venue for hosting exhibitions and other events. For example, an 
exhibition on the history of the field, co-organised with the Stiftung Topographie des Terrors, was advertised as such a project.

Six. To establish "digital and innovation centre," aimed predominantly at companies based in the IT industry. The centre should be housed in the H2rund part of the edifice, just next to the cour d'bonneur and close to the entrance hall. This is where the Deutsche Lufthansa was once headquartered, and where the US Air Force later opened the Officers' Casino (Offizierskasino) called Columbia Haus. Given the history of Tempelhof as a site of innovators and pioneers, this idea follows the tradition and esprit of the site. If carried out sensibly, successfully and with respect to heritage care guidelines, it could be a logic, viable way to make the building profitable without sacrificing its symbolic meaning (Thf Berlin g).

Seven. To establish "a centre for the creative ones." As opposed to the previously mentioned proposal, "a centre/quarter for the creative ones" (Kreativquartier) is presented through a number of meaningless slogans ("area full of exciting ideas," "space for... trying out/checking out," [the building being] "openly visible and visibly open," et cetera) (Thf Berlin h). The official rhetoric of the Tempelhof Projekt GmbH frequently mentions the idea of transforming the building into a "creative hub." However, not much information has been provided about the character, functioning and economic sustainability of such a hub.

Eight. The same could be said about the announced refurbishment of the Platz der Luftbrücke, or the circus right in front of the symmetrically laid-out entrance area of the impressive airport edifice, where the monument to the Airlift is located. Every year in May, speakers, invited guests and audiences gather to celebrate the anniversary of the Airlift. The space per se thus forms a key area of the whole complex, not only symbolically, but also architecturally. Several buildings around the circus were constructed at the beginning of the twentieth century when Berlin was perhaps still in the shadow of Vienna, yet definitely on its way to become the centre of modern culture in 20 years' time. Aviation, airmindedness and travel played a vital role within that Zeitgeist. Behind the Platz der Luftbrïcke, there is a neighbourhood called Neu-Tempelhof, also known as Fliegerviertel, which could be translated as “Aviators' Quarter/Neighbourhood." Neatly laid-out streets with orderly blocks of flats still remind an occasional wanderer that before both wars, Berlin was a flourishing, powerful city. Not without its flaws and problems, but with a spirit that has never been re-created since then. The whole borough of what is today TempelhofSchöneberg was naturally a part of the story: the presence of the enormous airfield, and with it the technical achievement as well as political use and misuse, were related to it. Therefore, in terms of landscape refurbishment, I argue that drawing inspiration from this aviation esprit and its finest accomplishments, and thus honouring the glorious past of the place, would be considerably more appropriate than trying too hard to come up with something übermodern and out-of-place.

In addition, several further steps have been taken: a new coffee house, called Café Orville's, has been opened in the former Officers' Casino (Offizierskasino) (Thf Berlin i); a 
couple of facility management companies have been hired to look after technical matters, security, landscaping and the like (Thf Berlin l); and an official press release has addressed the current state of the edifice, seen from a heritage perspective (Thf Berlin $\mathrm{m}$ ).

To conclude, suffice is to say that whilst the Tempelhof Projekt GmbH attempts to bring the building and its environs to life, the overall impression comes across as generally indecisive, and somewhat lacking a coherent basis. Ironically perhaps, the result of yet another Ideensammlung, or a "collection of ideas" on the future of Tempelhof, was presented as "recreation of the lively bustle from the era of the functioning airport" (Thf Berlin $\mathrm{n})$.

To complicate matters more, since October 2015 there have been many hundreds of migrants housed in the hangars, and later in container units, the so-called TempoHomes, on the apron.

After the edifice was photographed being encircled with armoured police vans, following massive fights amongst respective groups of migrants (Portmann et al. 2015; Bachner 2016), the discrepancy between what was happening on the open field, as opposed to what was going on in the closed interior parts of the building, could hardly be greater.

Another disturbing piece of news resurfaced only recently, when local newspapers announced that the Senate of Berlin, dominated by Social Democrats, has been aiming for a circumvention of the result of the 2014 referendum: the Senate strives to force through the redevelopment of the edges of the field again (Zawatka-Gerlach 2018). Even though the referendum result has been transformed into a piece of law - the so-called TempelhofGesetz - it could theoretically be changed in the local parliament. The Social Democrats are arguing with a lack of available housing space in the city, yet this justification is hardly plausible, given the vast brownfields in the city itself and on its edges, as well as a number of vacant lots right in the central area, these being still the consequence of World War II bombings. There is no doubt that Berlin's population keeps fluctuating, and that suitable housing possibilities are crucial. However, attempting to build on the Tempelhof field is the laziest option, utterly undermining the credibility of the current political establishment. The Governing Mayor of Berlin, Michael Müller (SPD/the Social Democratic Party of Germany), attended some of the afore-mentioned city conferences in the Tempelhof hangars in 2013. Not a Mayor yet, back then he was advocating, as a member of the Senate, the redevelopment and claimed to do everything for the benefit of the locals. Members of the audience were shouting at him in anger, and the whole 'conference' ended in a bizarre deadlock. Now, more than five years after the victory of the voxpopuli over the politicians, the local government apparently assumes that people have forgotten everything.

This is not the case, though. The most active public initiative, the 100\% Tempelhofer Feld, keeps informing on what is going on (Thf 100). Enthusiasts organize various events on the field, including music and summer festivals. In autumn 2018, there could be seen a flock of sheep peacefully grazing on the field, to the delight of passers-by. The eccentric gardeners are still there, as are kite-flyers, joggers, walkers and even the proverbial urban flâneurs. 


\section{Conclusion}

Over the past decade, a rather uncommon but evidently thriving mixture of users of the field has gradually evolved: some would even call it a subculture sui generis. A tension between the members - or at least some of them - of this large, loosely defined group on the one hand, and the Senate of Berlin on the other hand, is clearly present. It is now up to the Senate to provide the next stimulus and shape the discourse, and it is up to the Tempelhof Projekt GmbH to present coherent long-term plans about the building and the field clearly enough, so that a meaningful discussion can be underpinned by wellknown proposals as well as established facts. People who wanted to keep the field open to everyone have already achieved what they had been striving for. They mobilised about 740,000 Berliners to vote the redevelopment plan down. What is at stake now is the upkeep of the liberated field, as well as ensuring a viable future use of the grade-listed building. Tempelhof is now in a state of transition, as is Berlin and arguably the whole of Germany. Let us hope for the better.

\section{References}

ADEy P. 2010. Aerial Life. Spaces, Mobilities, Affects. Oxford: Wiley-Blackwell

ADEY P. 2011. 'Ten thousand lads with shining eyes are dreaming and their dreams arewings': affect, airmindedness and the birth of the aerial subject. Cultural Geographies 18(1): 63-89.

AhlBrecht B.-R. \& Henning H.-J. 2008. Der Flughafen Berlin-Tempelhof. Bilder der Luftfahrt. Erfurt: Sutton Verlag.

Alberts H. C., Bowen JR. J. T. \& Cidell J. L. 2009. Missed Opportunities: The Restructuring of Berlin's Airport System and the City's Position in International Airline Networks. Regional Studies 43(5): 739-758.

ATKINSON D. 2007. Kitsch Geographies and the everyday spaces of social memory. Environment and Planning A39: 421-440.

AugÉ M. 2008. Non-places. An Introduction to Supermodernity. London: Verso; $2^{\text {nd }}$ English language ed.

Ausgrabungen Tempelhof 2018. Archäologische Ausgrabungen Tempelhofer Flugfeld http://www.ausgrabungen-tempelhof.de/ Accessed 28 Nov 2018

Ayrault P. \& Bowdler R. 2000. Berlin-Tempelhof, Liverpool-Speke, Paris Le Bourget: années 30 architecture des aéroports. Paris: Éd. du Patrimoine

BABAN F. 2006. From Gastarbeiter to "Ausländische Mitbürger”: Postnational Citizenship and In-Between Identities in Berlin. Citizenship Studies, 10(2) : 185-201.

BACHNER F. 2016. Messerangriff auf homosexuelle Flüchtlinge - Polizei ermittelt. Der Tagesspiegel 23 Jan 2016

Cwerner S., Kesselring S. \& URry J. (eds), 2009. Aeromobilities. London: Routledge.

DiTTRICH E. 2005. Ernst Sagebiel. Leben und Werk, 1892-1970. Berlin: Lukas Verlag.

DitTRICH E. 2006. Der Flughafen Tempelhof. In Entwurfszeichnungen un Modellen, 1935-1944.

Berlin: Lukas Verlag; 2. Ausgabe

DiE Welt 2016a. 40.000 Türken demonstrieren in Köln für Erdogan. Die Welt 31 July 2016

Die WeLt 2016b. AKP wirft Deutschland "Doppelmoral" vor. Die Welt 3 Sept 2016. 
FABRicius M. 2019. Am 8. November fällt der Flughafen Tegel in den „Schlummerzustand.“ Die Welt 29 Nov 2019. Accessed 13 Dec 2020

BER-Eröffnung: Am 8. November schließt der Flughafen Tegel - WELT

Flughafen Tempelhof https://www.thf-berlin.de/ Accessed 28 Nov 2018

FrançOIs É. \& SCHulze H. 2001. Deutsche Erinnerungsorte. München: C.H. Beck (Vol. I III).

Gordon A. 2008. Naked Airport. A Culture History of the World's Most Revolutionary Structure. Chicago \& London: University of Chicago Press.

Huschke W. J. 2008. The Candy Bombers. The Berlin Airlift 194849, the Technical Conditions and Their Successful Transformation. Berlin: Berliner Wissenschafts-Verlag. $2^{\text {nd }}$ ed.

Huyssen A. 2003. Present Pasts. Urban Palimpsest and the Politics of Memory. Stanford: Stanford University Press.

LADD B. 1998. The Ghosts of Berlin. Confronting German History in the Urban Landscape. Chicago \& London: Chicago University Press

MeINERs A. 2011. Tempelhof-gestern, heute und morgen. Berlin: Nicolai Verlag.

NeEdHAm A. 2011. Anselm Kiefer: "Art is difficult, it's not entertainment." The Guardian

9 Dec 2011.

NORA P. 1989. Between Memory and History: Les Lieux de Mémoire. Representation 26: 7 24.

NORA P. 1996. Realms of Memory: Rethinking the French Past. New York: Columbia University Press (Vol. I - III).

Portmann K., Hasselmann J., Görke A. \& Dassler S. 2015. Massenschlägerei in Tempelhof: Henkel warnt vor Eskalation. Der Tagesspiegel 30 Nov 2015.

ReChenberg C. 2013. Innovationsfeld Tempelhof: Möglichkeitsräume von Planungsinstrumenten. Hamburg: Diplomica Verlag.

REESE H.-G. (ed.), 2009. 50 Jahre Stiftung Luftbrückendank 1959 - 2009. Berlin: Stiftung Luftbrückendank

SCHOElKopf K. 2008. Gesundheitszentrum und Sonderflughafen. Berliner Morgenpost, 25 April 2008

https://www.morgenpost.de/printarchiv/berlin/article102675780/Gesundheitszentrum -und-Sonderflughafen.html Accessed 12 Dec 2020.

Strauss S. 2013. Bässe bis Britz. Die Konzerte der Ärzte und der Toten Hosen in Tempelhof waren trotz Lärmschutz kilometerweit zu hören. Berliner Zeitung 13 Aug 2013. THE ECONOMIST 2012. Berlin's Tempelhof airport: No 'crappy capitalist luxury project' please. The Economist 26 Apr 2012

THF BERLiN a. https://www.thf-berlin.de/ Accessed 28. 11. 2018 and 16. 2. 2020

THF BERLIN b. https://www.thf-berlin.de/standortentwicklung/tower-thf/ Accessed 1 Dec 2018

THF BERLIN c https://www.thf-berlin.de/standortentwicklung/geschichtsgalerie/ Accessed 28 March 2019

THF BERLIN d https://www.thf-berlin.de/standortentwicklung/tower-thf/ Accessed 14 Oct 2020

THF BERLIN e https://www.thf-berlin.de/standortentwicklung/besucherzentrum/ Accessed 1 Dec 2018 
THF BERLIN f https://www.thf-berlin.de/service/besucherzentrum-check-in/ Accessed 16 Feb 2020.

THF BERLIN g https://www.thf-berlin.de/standortentwicklung/bauteil-h2rund/; Accessed 29 Nov 2018.

THF BERLIN h https://www.thf-berlin.de/standortentwicklung/kreativquartier/; accessed 29 Nov 2018.

THF BERLIN i https://www.thf-berlin.de/standortinfos/unternehmen-vorort/detail/?tx_news_pi1\%5Bnews $\% 5 \mathrm{D}=321 \& \mathrm{cHash}=$ f12f2c37f9cbdceb32989a780ed51 f59 Accessed 16 Feb 2020.

THF BERLIN 1 https://www.thf-berlin.de/service/neuigkeiten/artikel/neue-facilitymanagement-dienstleister-am-flughafen-tempelhof/ Accessed 16 Feb 2020

THF BERLIN m https://www.thf-berlin.de/service/neuigkeiten/artikel/pressemitteilungzum-gebaeudezustand-des-flughafen-tempelhofs/ Accessed 16 Feb 2020

THF BERLIN n https://www.thf-berlin.de/beteiligung/ Accessed 29 Nov 2018

THF 100 http://www.thf100.de/start.html Accessed 28 March 2019

Till K.E. 2005. The New Berlin. Memory, Politics, Place. Minneapolis, MN \& London: University of Minnesota Press.

Zadrazilova D. 2020. Tempelhof Airport in Berlin: Conflicting Realms of Heritage, in T. Carter, D.C. Harvey, R. Jones \& I.J.M. Robertson (eds.), Creating Heritage: Unrecognised Pasts and Rejected Futures. Abingdon \& New York: Routledge: 81-96.

ZawatKa-Gerlach U. 2018. Bauen auf dem Tempelhofer Feld? Tagesspiegel 17 Nov 2018 https://www.tagesspiegel.de/berlin/trotz-volksentscheid-bauen-auf-dem-tempelhoferfeld/23649592.html Accessed 1 Dec 2018 